\title{
Argentine Social Protection in a Context of Demographic Transition
}

\author{
Rafael Rofman and Ignacio Apella*
}

World Bank, Práctica Global de Protección Social y Empleo, Buenos Aires

\begin{abstract}
Argentina is going through a process of demographic transition that will result in an older population structure. The demographic transition has direct effects on the quantity and adequacy of social protection transfers, with particular emphasis on those related to pensions. The main objective of this paper is to identify the potential trends of social protection expenditures in an aging context. On the basis of the expenditure profile by age, we apply National Transfer Accounts methodology to simulate social protection expenditures until 2100. The results suggest that, under various alternative social security coverage scenarios, the demographic transition process would lead to an increase in future social protection expenditures, reaching 16\% of gross domestic product (GDP) by 2050 and exceeding 24\% in 2100.
\end{abstract}

Keywords: Social protection; aging; poverty; pensions; Argentina.

* Article received on September 20, 2015; final version approved on March 2, 2016. The authors thank Fabio Bertranou for his comments. This article is based on a chapter in the book Los años no vienen solos: oportunidades y desafios economicos de la transicion demografica en Argentina, edited by the authors and published by the World Bank in 2014.

Rafael Rofman has a Master's in Social Demography from the Universidad Nacional de Luján and a Ph.D. in Demography from the University of California, Berkeley. He is the World Bank Program Leader for Education, Health, Social Protection and Labor, and Poverty, covering Argentina, Paraguay, and Uruguay, and is the author of numerous studies on adult mortality, aging, and social security.

Ignacio Apella has a Master's in Economics from the Universidad de Buenos Aires and is an economist in the World Bank's Global Practices in Social Protection and Labor in Latin America. He has worked in several countries in the region including Argentina, Bolivia, Chile, El Salvador, Mexico, Peru, and Uruguay. He specializes in systems of social protection, labor economics, health economics, industrial organization and microeconometrics, and is the author of various publications in specialized journals. Emails: rrofman@worldbank.org; iapella@worldbank.org

Vol. XLIII, № 78, First Semester 2016: pages 89-119 / ISSN 0252-1865

DOI: http://dx.doi.org/10.21678/apuntes.78.836

Copyright 2016: Centro de Investigación de la Universidad del Pacífico 


\section{Acronyms}

AFIP Federal Administration for Public Revenue (Administración Federal de Ingresos Públicos)

AFJP Retirement and Pension Fund Administrators (Administradoras de fondos de jubilaciones y pensiones)

ANSES National Social Security Administration (Administración Nacional de Seguridad Social)

AUH Universal per Child Allowance (Asignación Universal por Hijo)

CELADE Latin American and Caribbean Demographic Center (Centro Latinoamericano y Caribeño de Demografía)

CPI Consumer price index

DNPSS National Office for Social Security Policies (Dirección Nacional de Politicas de Seguridad Social)

EAP Economically active population

EPH Permanent Household Survey (Encuesta Permanente de Hogares)

GDP Gross domestic product

INDEC National Institute of Statistics and Censuses (Instituto Nacional de Estadistica y Censos)

MTEySS Ministry of Labor, Employment, and Social Security (Ministerio de Trabajo, Empleo y Seguridad Social)

SIF Savings, investment, and financing

SIJP Integral System of Retirement and Pensions (Sistema Integrado de Jubilaciones y Pensiones) 


\section{INTRODUCTION}

Social security is usually defined as the set of programs and policies, referred to as social insurance, that have as their objective to cover households' specific risks of income loss. In general terms, social security is established in order to provide certainty and insure individuals against the risk of income loss or spending shocks associated with retirement in old age, disability, sickness, accidents, and death.

In turn, social protection encompasses a field that is broader than social security, including not just traditional contributory social security, but also other non-contributory transfer schemes. Thus, social protection programs include contributory social security (old-age and disability pensions; death benefits; occupational hazards; unemployment benefits; family allowances) and non-contributory transfer programs, usually aimed at reducing the incidence of poverty.

The funding of non-contributory social protection comes from general revenues, specific taxes, and direct contributions from the state. Social security, on the other hand, tends to cover fewer people and is financed by three types of payroll contributions (from the insured, employers, and the state).

Non-contributory programs have traditionally been very limited in their reach, both in terms of budgeting and coverage. Nevertheless, in recent years we have begun to observe a change in trends in social protection systems in the region, with focus on these types of programs progressively increasing. In Argentina, the implementation of the Unemployed Heads of Household Plan, the Social Security Inclusion Program (commonly referred to as the "Moratorium") and the Universal per Child Allowance (AUH) are clear examples of the expansion of coverage to the population that has been excluded from the formal labor market and is living in a situation of poverty or vulnerability.

From a lifecycle perspective, the monetary transfers for social protection reach the population in different ways for each age group. For example, family allowances are transfers to children; unemployed young adults are protected by contributory unemployment insurance as well as training and employment insurance; while older adults receive protection through pension programs.

Argentina is undergoing in a demographic transition process towards an older population structure. This is a result of a decrease in fertility and mortality in the last decades. Based on this process, growth is predicted in both the total dependency ratio and the senior 
citizen dependency ratio in the coming decades. While the total dependency ratio was $55 \%$ in 2010 , it is estimated that it will reach $72 \%$ by 2100 . Furthermore, the proportion of the adult population over age 65 relative to the working-age population was 10\% in 2010 and is projected to reach $25 \%$ by 2100 .

The increase in the number and proportion of the population over age 65 in many countries around the world has generated interest in the impact that this trend will have on social security systems. The apparent implication of this phenomenon is pressure on the sustainability of public and private expenditures on pensions. As social security spending increases, so too do controversies over the funding mechanisms for current and future benefits.

In this context, the process of demographic transition that is pushing Argentina toward an older population structure has direct effects on the quantity and adequacy of the transfers made through the social protection system. This is the result of two factors: a) the demographic transition itself, which results in a change in the sizes of the contributory and beneficiary population groups as the population ages; and b) the changes in public policy introduced as a response to these demographic trends. For this reason, this study presents an estimation exercise for coverage and the amounts transferred through social protection programs according to several alternative scenarios, with the goal of evaluating the potential costs of the system in different contexts.

Long-term projections are necessary in order to evaluate how the system will react in response to expected changes in economic, political, and demographic conditions. These are not predictions to "correctly guess the future," but rather to allow us to evaluate the system's prospects, given certain reasonable hypotheses about the long-term evolution of several determinant variables. Additionally, the present exercise will allow us to evaluate the impact of alternative hypotheses and/or reforms of current regulations on the coverage and financing of social protection.

\section{POPULATION DYNAMICS IN ARGENTINA}

Argentina, together with Uruguay and Chile, was one of the Latin American countries that underwent the process of demographic change the earliest, starting in the first half of the last century. The sustained reduction in fertility and mortality began with the middle class, generally in urban areas in the central regions of the country, later spreading slowly to the rest of the population. 
Unlike in other countries, in Argentina this transition took place in two clearly defined stages. Between the beginnings of the 20th century and 1950, there was a decline in fertility which led to the first process of population aging. However, this process came to a halt starting in 1950 and even reversed slightly at the end of the 1970s, before its marked resumption from the 1990s. The effect of these trends can be observed in the rates of dependence of the population, which take into consideration the ratio between the dependent population of youth, senior citizens or both and that of economically active-age adults (between 15 and 64 years of age). Graph 1 shows these trends from the end of the 19th century to projections for the end of the current century.

\section{Graph 1}

Dependency in youth, senior citizens, and total, Argentina, 1895-2100 (rates and projections)

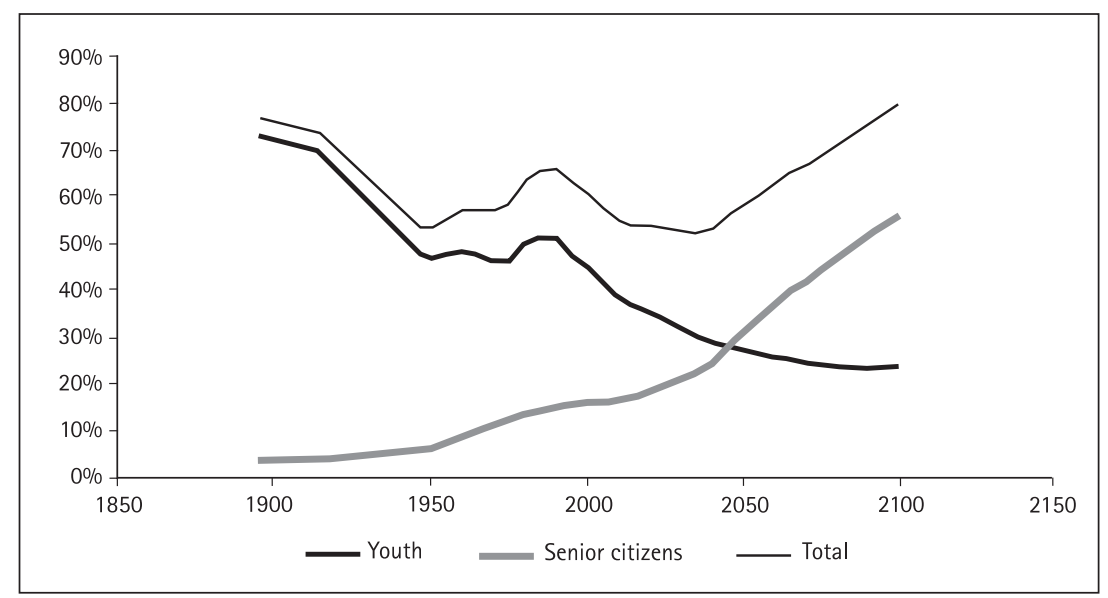

Source: Censo Nacional de Población-INDEC $(1895,1914,1947)$ and CEPAL (2012).

Graph 1 shows the sustained growth trend in the weight of the senior citizen population, which increased from a proportion of less than $4 \%$ of young adults in 1900 to $17 \%$ currently, and is expected to exceed $50 \%$ by the end of the century. On the other hand, the relative importance of children has declined, although with the aforementioned reversal between 1950 and 1990. As a result of these two effects, a significant decline in the total dependency rate in Argentina was recorded in the first half of the 20th century, before stopping and reversing itself for the most part until the 1990s, to later fall again between the beginning of the 1990s to the end of the 2030s, when the increasing trend of dependency of senior citizens became more important. 
The importance of this indicator is based on the concept of a demographic bonus. The demographic bonus is defined as the period of demographic transition during which the total proportion of the working age population increases, thereby generating an opportunity for economic growth due to the availability of human resources. 'In this sense, Argentina has had two periods of history with a very favorable context due to the demographic bonus. The first was between 1915 and 1950, when most of the social security system was developed; and the second was between 1990 and the subsequent 15 or 20 years, when the principal challenge was to create the framework for an economy that was able to sustain the quality of life of an increasingly aging population.

Currently, Argentina has begun a 30-year period with the most favorable population age structure, which could be conducive to economic growth. At the same time, this demographic opportunity could offer the ideal context for putting in place sustainable long-term public policies and generating economic and social opportunities, considering the gradual demographic change. There are two reasons for this: a) the slow pace of institutional changes; and b) those who will be senior citizens starting in 2050 are those who are currently entering the labor force and, thus, the decisions they make now are conditioned by the current rules of the game. Decisions made by people throughout their adult life are framed within the context of current and future social and economic institutions, which define economic security in old age. At the same time, political realities normally impose a long period of transition before a new regulatory framework is implemented. The longer a reform is postponed, the greater the need for it and the more drastic its implementation will be. As a result, the cost of existing programs may continue to increase for various years during the long period of transition before the stabilizing effects of the reform begin to be felt.

One example are the reforms implemented in European countries that are intended to improve the sustainability of their pension systems. In these reforms, the rise in the legal age of retirement, intended to increase the economic and financial contribution of the working age population and to reduce the pressure on social security expenditures, has turned out to be difficult to put into practice. Indeed, the recent European experiences are not encouraging. In France, the proposal to increase the legal retirement age by two years encountered fierce political opposition in 2010, including mass strikes and demonstrations, and was reversed in 2012. In Italy, a similar reform was promulgated in 2012, raising the minimum retirement age to 66 for men and women in 2018; this proposal was strongly resisted but was approved in the context of a critical economic situation.

1. Obviously, the bonus represents only an opportunity. External conditions related to macroeconomic dynamics, public policies, and growth strategies are what allows this opportunity to be taken advantage of to a greater or lesser extent. 


\section{SOCIAL PROTECTION IN ARGENTINA}

Argentina is part of a group of countries considered "pioneers" in Latin America in the development of their social protection systems, together with Chile, Cuba, and Uruguay. These countries introduced legislation that established old age and life insurance for some groups of organized workers at the beginning of the 20th century. The development of social protection took place gradually and was linked to formal employment, thus excluding unemployed or informal workers. The social security programs for the formal sector include pension transfers, family allowances, and contributory unemployment insurance. These schemes originated in negotiations between unions and their employers and during the length of the century that led to national programs managed by the state.

\subsection{The pension system}

The first formal pension scheme in Argentina was approved in 1904 with the creation of the Civil Fund, which was aimed at workers that held permanent positions in the government administration and whose salaries were part of the Annual Budget of Expenditures of the Nation (teachers and employees of the National Education Council, employees of official banks and the Argentine railroads, judicial magistrates, and elected officials). The system expanded slowly, and beginning in 1944, the process of expanding pension benefits to the entire working population, including independent workers and employers, commenced. In 1969, the various existing systems were unified to create the National Social Security System. During the 1980s and the beginning of the 1990s, problems of financial sustainability worsened, in part because of the maturation of the system and the difficulty of incorporating new groups of workers, and in part because of the population aging process and the impossibility of maintaining the generous benefits provided for in this framework (such as a replacement rate of $82 \%$ ).

In this context, in 1993, a structural reform of the pension system was carried out. The Integrated Retirement and Pension System (Sistema Integrado de Jubilaciones y Pensiones, SIJP) was created, comprised of two regimes: one public, organized as a pay-as-you-go scheme and managed by the National Social Security Administration (Administración Nacional de Seguridad Social, ANSES); and a regime based on individual capitalization and administered by private firms, the Retirement and Pension Fund Administrators (Administradoras de Fondos de Jubilaciones y Pensiones, AFJP). In addition, some parametric changes were introduced, including increasing the minimum retirement age from 55 to 60 for women and from 60 to 65 for men, along with an increased requirement for years of contribution (30 instead of 20 years), and an increase in the workers' contribution rate, from $10 \%$ to $11 \%$ of salaries. 
From its implementation, the design and functioning of the SIJP was the object of strong debate centered on its lack of competency, the low yield of its funds, and the cost of the system. At the end of 2008, the capitalization regime was permanently eliminated, with all contributions going to the public system. This reform, however, did not modify the principal parameters of the system (such as the rate of contributions, the minimum retirement age, or the years of contributions required to receive a pension), which remained at the levels established in 1993.

\subsection{The family allowances system}

Family allowances consist of social income transfers, whereby all formal workers receive an amount based on the size of the family that they support. Therefore, these allowances are considered to be a complement to family income, aimed at increasing per capita resources in larger households (Rofman et al. 2008).

The system was first introduced in Argentina in the mid-1930s as a maternity subsidy. In 1940, a per-child subsidy was incorporated, although this was only in the banking sector. Starting in 1957, the system was formalized with the creation of compensatory funds established through collective bargaining, and the subsidies were subsequently extended to children under the age of 15 and the disabled.

The funds' source of financing came from an employer payroll contribution equivalent to between $4 \%$ and $5 \%$, which was later increased to $10 \%$ and $12 \%$, and in mid-1985 was reduced to $9 \%$. In 1991, the payroll contribution designated for family allowances was reduced to $7.5 \%$ and the remaining $1.5 \%$ was earmarked for the creation of the National Employment Fund. Also in 1991, the funds were dissolved and social security benefits were unified, including the family allowances system, under the jurisdiction of ANSES (Bertranou and Bonari 2005).

In 1996, a reform of the family allowances system was proposed with the objective of achieving greater equity. With a clear redistributive purpose, on the one hand, the reform established differentiated rates of benefits according to the salary levels of workers eligible for this contributory benefit; and on the other hand, four salary ranges that offered greater benefits to lower paid workers were established. Workers with salaries above a fixed limit were not directly eligible.

The benefits offered were for the following: childbirth, maternity, adoption, marriage, prenatal, children, disabled children, and school support. The per-child benefits, school support, and maternity benefits were paid for directly by employers, while birth, adoption, and marriage benefits had to be applied for at the ANSES. 
However, the law - approved during a period of economic stability - did not provide for systemic adjustment mechanisms for benefit amounts, nor did it consider lower and upper limits for the salary bands that determined eligibility for various benefits. For these reasons, adjustments were discretionary and, in almost all the cases, slower than the evolution of salaries and prices.

In 2012, the structure of salary bands was modified. Starting in that year, instead of considering the income of the adult responsible, household income was taken into account, adding together the formal salaries of both the husband and wife and implicitly recognizing that the benefit should not be determined by the income of one person but that of the household as a whole.

\subsection{Unemployment insurance}

One of the instruments used to protect workers from the risk of a reduction in income associated with job loss is unemployment insurance. The traditional design of these programs is based on the principle of insurance. This, complemented by assistance programs, constitutes one of the most used protection mechanisms in industrialized countries.

The main benefit of unemployment insurance is to offer income security in order to avoid large fluctuations in household consumption when a household member is unemployed, as well as offer a base of stability that allows them to search for employment and rejoin the labor market under better conditions.

In Argentina, unemployment insurance legislation was passed in 1991 (Law 24,013, National Employment Law). The workers protected from the risk of unemployment are those who have a labor contract governed by the Labor Contract Law (Law 20,744, which covers private sector salaried workers) and those included in the National Regime for the Construction Industry, who have special status.

Workers can access the benefit if they are dismissed from their job in the formal sector, contributed to the National Employment Fund for a minimum period of six months during the three years prior to losing the job, and are not receiving social security benefits or non-contributory pensions.

The benefit is equivalent to a percentage of the net amount of the highest paid month during the six months prior to being dismissed. This percentage, which is currently 50\%, is applicable during the first four months of the benefit and is established by the National Council of Employment, Productivity, and Living Minimum Age. 
In order to provide the incentive to work and to seek employment, the benefit decreases the longer unemployment lasts: from the fifth to the eighth month, the benefit is equal to $85 \%$ of the amount received during the first four months, while the benefit from the ninth to the twelfth month falls to 70\%. At the same time, the benefit has a lower limit of 250 Argentine pesos and an upper limit of 400 pesos; the average benefit is equivalent to 357.51 pesos.

In Argentina, even though the scheme has existed for more than 20 years, its reach - measured as the ratio between beneficiaries and the total number of unemployed persons - is low. In this sense, labor informality is an obstacle to the program's operation because, as a contributory scheme, only formal salaried workers can join.

\subsection{Between Bismarck and Beveridge}

Beginning in the mid-2000s, several measures aimed at universalizing the social protection system were introduced. They targeted two dependent population groups in particular: senior citizens and children. The two emblematic programs of this type are the Social Security Inclusion Program (Moratorium) and AUH.

In the case of senior citizens, several studies ${ }^{2}$ highlight the decreasing trend in coverage since the beginning of the 1990s, explained by the combined effects of a high level of labor informality and stricter eligibility requirements introduced in 1994. A study carried out by the Secretariat of Social Security, ${ }^{3}$ analyzing data from 1994 to 2003, shows that nearly $80 \%$ of the employed population was affiliated with the social security system. However, among this group, only $20 \%$ (16\% of the EAP) had made regular contributions at least $80 \%$ of the time and would thus be able to meet the requirements to retire when they reached the minimum age. In contrast, around 50\% had made less than one-third of the contributions. When this group is combined with those who never made a contribution during their working life, it becomes clear that around $60 \%$ of the population will never be able to retire.

With the goal of reducing the coverage gap among the unemployed population, beginning in 2005, the Moratorium was implemented, establishing a regime of payment options for independent workers who are debtors to the pension system. This initiative allowed any citizen who met these minimum age requirements but not the required number of contribution years to declare a debt corresponding to the contribution shortfall through

2. See, for example, Rofman et al. (2008); MTEySS (2005).

3. Dirección Nacional de Políticas de Segurida Social (DNPSS), on the basis of AFIP (AFIP; MTEySS 2005). 
the independent workers' regime, and to set up a payment plan that would allow them to make payments at the same time as they received benefits.

Additionally, these access options for pension benefits were extended to survivors of deceased workers, with the goal that these persons could obtain survivor's benefits. The voluntary debt regularization regime created by these regulations is permanent, but it only recognizes contribution years prior to 1994, which means that the option to join the regime will gradually disappear.

The impact of the Moratorium was massive: between the end of 2005 and 2011 more than 2.7 million retirement benefits were awarded through this mechanism. As a result, by the end of 2011, the total number of benefits in the national system had reached 6.1 million, while around 1 million people had received non-contributory pensions for disability, old age, or ex gratia. This had a significant impact on coverage levels beginning in 2006, which marked a sharp departure from the previous trend. In this regard, coverage of senior citizens recovered quickly between 2005 and 2006, when it reached 84.3\%, and continued growing gradually until reaching 90.8\% of the population over age 65 in 2011.

In the case of the population group under age 18, in October 2009, family allowances were expanded to children of the unemployed and workers in the informal sector. This initiative, called the Universal per Child Allowance (AUH), establishes that any family whose members do not participate in the formal labor market will receive 340 pesos per child (in 2012). ${ }^{4}$ Eighty percent of this amount is transferred monthly and the remaining $20 \%$ is delivered annually when the family presents documentation to prove school attendance for children over age five and checkup and vaccination certificates for those aged four and younger. According to Rofman and Oliveri (2012), the AUH has not significantly increased its coverage since it was created, remaining at around 3.5 million children at the end of 2011.

Graph 2 presents ANSES expenditures as a percentage of GDP for each budget category. Between 1998 and 2012, social security benefit expenditures grew by 50\%, as a percentage of GDP, increasing from $4.9 \%$ to $7.4 \%$. This is the result of various factors, among them: the increase in benefits, first discretionarily and subsequently through an automatic update mechanism; and the inclusion of 2.5 million beneficiaries through the Social Security Inclusion Program. The latter signified an average expenditure increase of $2.1 \%$ of GDP between 2008 and 2012.

4. Originally the amount was 180 pesos. 


\section{Graph 2}

National Social Security Administration expenditures by budget category, Argentina, 1998-2012 (as \% of GDP)

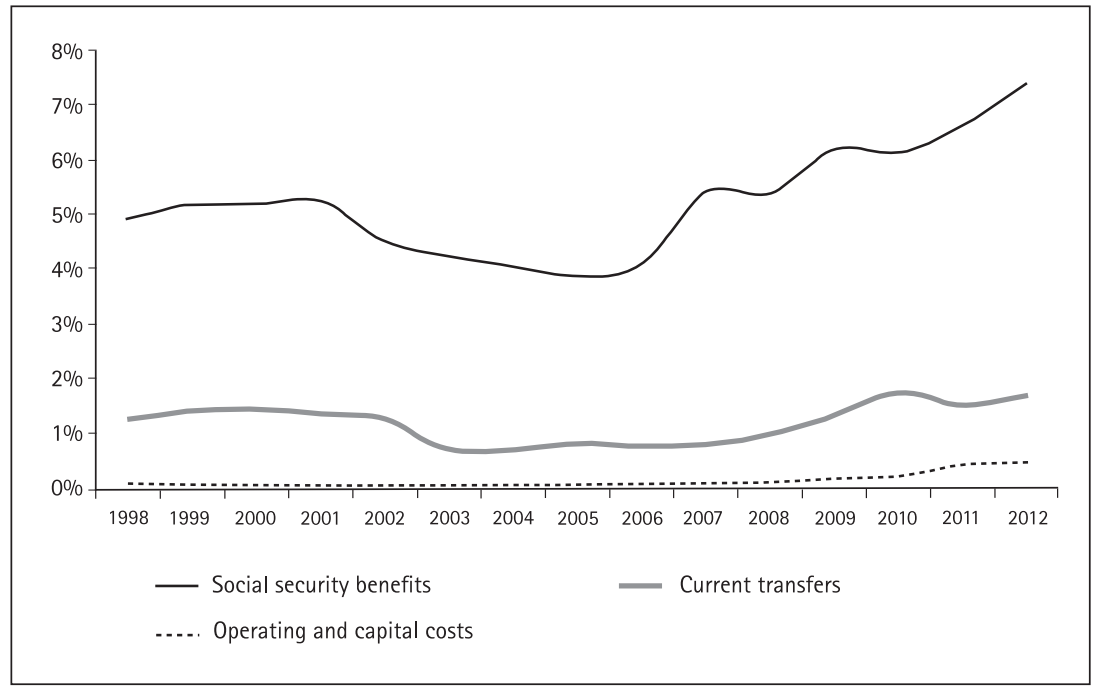

Source: Compiled by authors on the basis of data from the AIF-ANSES database and the Secretariat of Finance.

In the same way, following a period of contraction, transfers increased significantly starting in 2009 (27\%). This is related to the implementation of the AUH, which, on average, was equivalent to an additional $0.5 \%$ of GDP.

\section{SOCIAL PROTECTION AND POVERTY}

The gap and the incidence of poverty before and after taxes and transfers can be explained, in part, by differences in the taxation systems, but the role of public spending is critical. This expenditure - in addition to that intended to finance, among other areas, the education and health systems that make it possible for households to use certain goods and services - includes social protection policies such as monetary transfers that, for various reasons, households do not receive through the market.

The level of poverty is affected by labor and social protection policies because salaries, independent workers' income, and social protection transfers constitute the principal sources of income among Argentine households. The main goal of social protection programs is to replace labor income, ensure a base level of income or consumption, and even promote the accumulation of human capital. 
It is possible to identify the association between the goals of specific social protection programs and the age of beneficiaries. More specifically, insofar as pension programs are targeted at the senior citizen population with a view to replacing labor income during old age, family allowance transfers are designed to increase the disposable income of households that care for children. In between, there are transfers for unemployment insurance (contributory and non-contributory) targeted at young adults with problems finding work.

This distribution pattern gains relevance when we consider the heterogeneous profile of poverty according to the household life cycle. The evolution of the poverty profile by age is conditioned by the pattern of transfers and consumption throughout the life cycle. Three distinct periods can be identified. In the beginning, households initiate a process of accumulating assets and have a relatively low income as well as children of school age. Later, the second stage begins, during which the accumulation of assets starts to generate income for the households: income surpasses the level of consumption. Normally this period is associated with the maturation of the children, whereby they start their productive life. Finally, during the third stage, a reduction in assets takes place which is frequently associated with retirement from the labor market by the heads of household.

This division into three periods has significant consequences for the analysis of the incidence of poverty, insomuch as depending on where an individual is in the life cycle, the household may vary in the seriousness of the situation it confronts. For example, while the level of poverty during the first stage could be a consequence of the income-generation that takes place during the first years on the labor market with children to care for, a household that is barely above the poverty level in the second stage (labor maturity), could represent a more worrisome case given the fewer years that the worker has to save and accumulate assets. At the same time, the effect that generates a decline in income in the short term could be attenuated by the level of assets or savings which the household possesses at the moment of crisis.

Various authors have estimated the potential impact of income transfer programs on the incidence of poverty and income distribution in Argentina (Gasparini and Cruces 2010; Rofman and Oliveri 2012). These studies use the Permanent Household Survey (EPH) as their source of information and apply eligibility criteria to the surveyed population to estimate the impact of the programs. Following this methodology, in this section, we carry out an analysis based on a simulation exercise, prepared on the basis of EPH data, which enables consideration of the levels that the incidence of poverty reach with and without the income transfer programs.

First, poverty is calculated in function of income per adult-equivalent calculated by the National Institute of Statistics and Censuses (INDEC), which is transformed in function 
of the modeled scenario. In order to calculate poverty, we use the official poverty line for 1998 and an extrapolation from the official food basket in 2006, taking into consideration the rate of inflation reported for the Province of Santa Fe, given the problems of reliability associated with the official consumer price index (CPI).

Then, the potential beneficiaries of social protection programs (pensions, family allowances, and unemployment insurance) were identified, as was the value of the transfer received, in order to go on to estimate its potential impact.

For each household surveyed, the net income per adult-equivalent of all the transfers that were received or would potentially be received through the social protection system was compared. Both income from unemployment insurance as well as that from retirement and pensions are reported by households and are easily identifiable. Nevertheless, among those who receive pensions, it is not possible to distinguish those who receive them via the traditional contributory system from the beneficiaries of the Moratorium. For this reason, an estimate was prepared by distinguishing between those who receive benefits above and below the minimum income.

In order to identify the beneficiaries of the contributory family allowances, the exercise identified the households with children and with at least one spouse employed in the formal sector. Then the households were arranged on a scale of total formal household income and on scales of benefits and then a monetary value was assigned to each household in the form of allowance for number of children.

In addition, $\mathrm{AUH}$ beneficiaries are identified under a broader criteria than what is established by law, taking into account all households with children whose parents are unemployed or working in the informal sector. ${ }^{5}$

Below, we present the potential impact that social protection as a whole has on the incidence of poverty by the age of individuals for the years 1998 and 2012.

Graph 3 presents, for these years, the percentage of people in poor households by age group and the type of transfer received and the impact that the elimination of various social protection programs would have. Thus, it can be seen that in 1998 poverty affected $36.7 \%$ of the population, but if transfer programs had not existed, this level would have reached $43.4 \%$. The principal program that affects the poverty level is the social security

5. Gasparini and Cruces (2010) and Rofman and Oliveri (2012) provide various scenarios in which either independent employed formal workers or private school students or those with no schooling are excluded. 
system and, as a result, the simulated impact was concentrated on the elderly population. In 2012, the incidence of poverty was significantly lower (18.8\%) than the level recorded in 1998, a difference that was observed among all age groups. Here again, the importance of income transfers from the social protection system stands out because without these programs the proportion of individuals belonging to poor households would have reached $29.7 \%$. This impact is greater than that observed in 1998; the change is associated with the expansion of social protection coverage through non-contributory programs.

\section{Graph 3}

Individuals in poor households according to age group and type of transference, Argentina, 1998-2012 (in percentages)

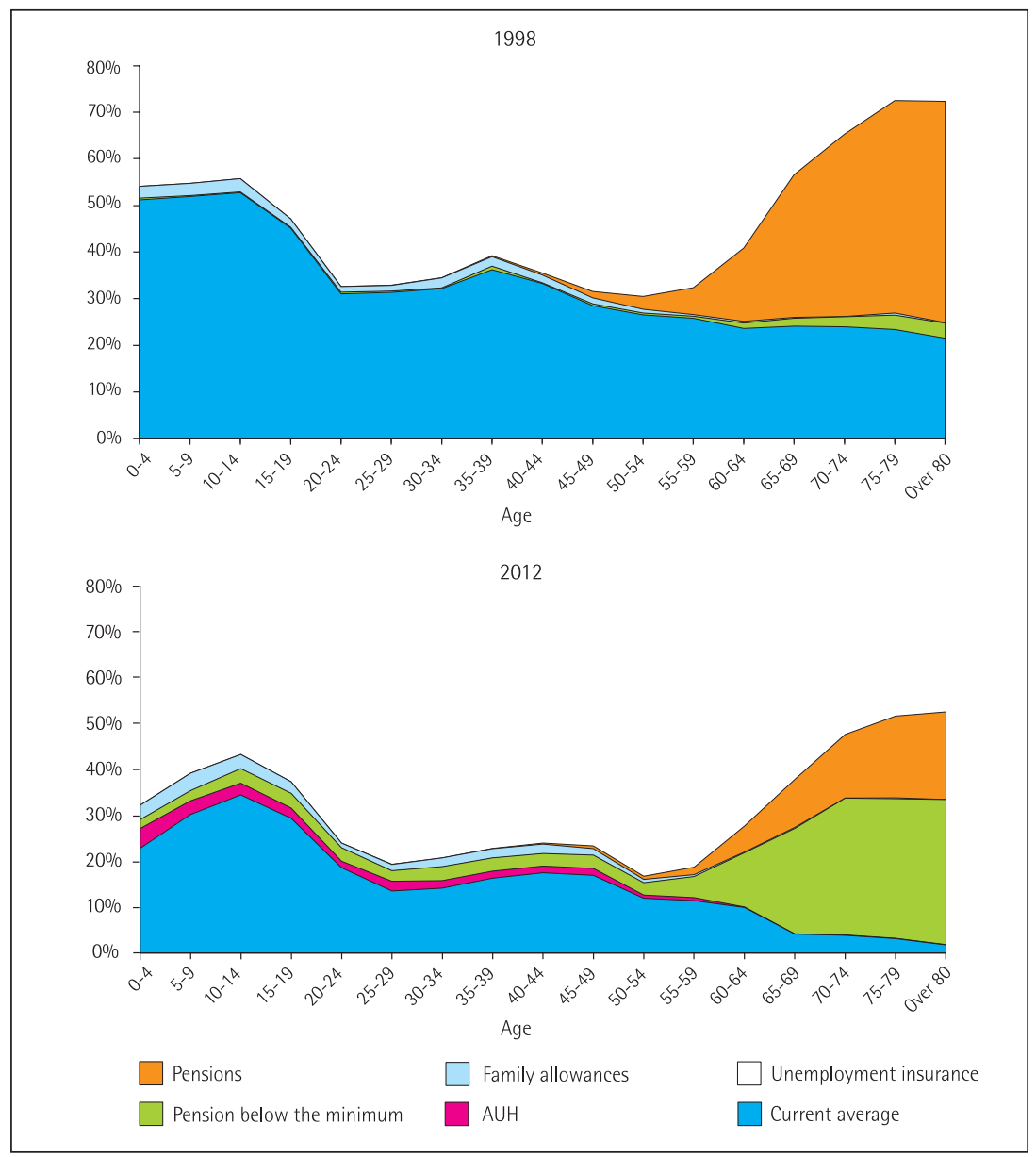

Source: Compiled by authors on the basis of the database of EPH-INDEC. 


\section{Graph 4}

Poverty gap by age and type of transfer, Argentina, 1998-2012

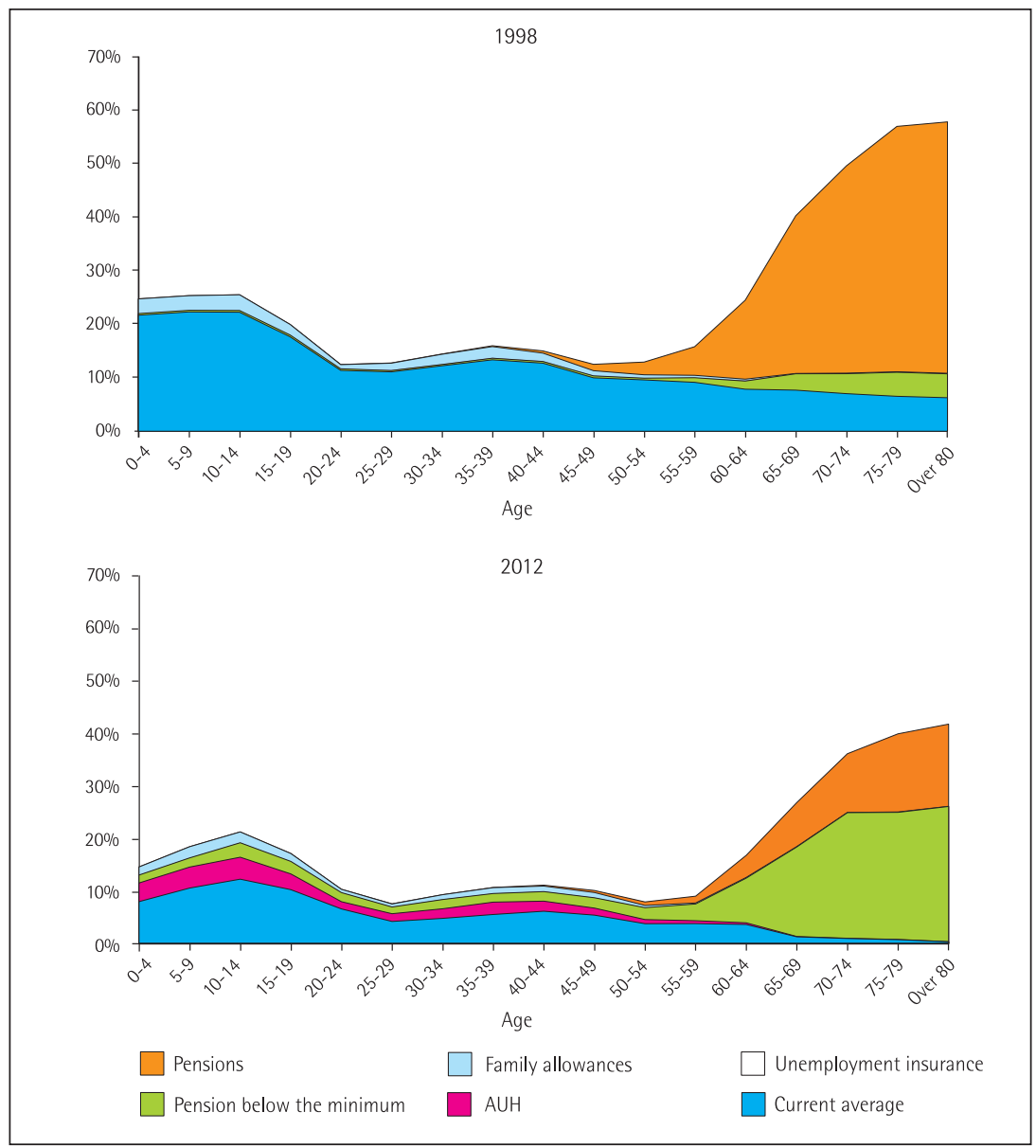

Source: Compiled by authors on the basis of the database of EPH-INDEC.

Graph 4 presents the poverty gap, i.e., the average percentage of income needed to reach the value of the poverty line, by age group and type of transfer. In 1998, those individuals living in poverty needed, on average, $12 \%$ of the value of the poverty line in order to reach it. Moreover, poor children had a gap of $21 \%$, while young adults and the elderly exhibited gaps of $11 \%$ and $7 \%$, respectively. Graph 4 helps highlight the importance of social protection programs not just in reducing the incidence of poverty, but also in reducing the gap for persons whose income remains below the poverty line. This is particularly noticeable 
among senior citizens, a group that without transfers from the social security system would have maintained an average gap of 51\% in 1998 and 36\% in 2012. In the case of family allowances, the effect is important, but less significant. This type of transfer increases the income available in young households. For this reason, its impact on both poverty reduction as well as on the gap is evident not only among children, but also among young adults.

The role that the two programs implemented during the last decade played in expanding social protection coverage is clearly illustrated in graphs 3 and 4 . The AUH had the effect of reducing total poverty by approximately 1.7 percentage points, with an expected concentration among children and the young adult population, enabling a potential reduction of poverty of between 3 and 1.2 percentage points, respectively. Along with contributory family allowances, this program facilitated a joint reduction of 3.4 points, with the greatest effect felt among children (6.0 points). Even though the potential impact on incidence was notable, it also enabled a reduction of the gap by $7 \%$, with the effect focused on children and young adults $-14 \%$ and $6 \%$, respectively.

With respect to senior citizens, the impact of the traditional contributory pension system (15 points) in 2012 is summed with the impact of the Moratorium and non-contributory pensions (29 points). The expansion of pension coverage through the Moratorium signified the integration of a large number of the senior citizens that had been excluded from receiving a social protection transfer and enabled them to rise above the poverty line.

\section{SOCIAL PROTECTION BENEFICIARIES IN 2010}

In this section, we present an approximation of the beneficiary profile of social protection programs, based on estimates made using information available from the EPH and adjusting these values as a function of the data from ANSES ${ }^{6}$ administrative records. Graph 5 presents the beneficiary profile for social protection by age group and type of transfer received in 2010.

Argentine social protection is characterized by its concentration of benefits on the two most vulnerable age groups in terms of income: children and senior citizens. In 2010, the total beneficiaries of income transfers for family allowances included a little over 6.7

6. The EPH does not specifically ask whether respondents receive family benefits. Thus, this population was identified indirectly based on the programs' eligibility criteria. Gasparini and Cruces (2010) and Rofman and Oliveri (2012) propose various scenarios in which either formal independent workers or students in private schools or with no schooling are excluded. Retirees, pensioners, and the beneficiaries of unemployment insurance are identified based on their direct declarations of having received income from retirement benefits, pensions, and/or unemployment insurance, respectively. 
million children, with $48 \%$ receiving contributory benefits and $52 \%$, the AUH. For their part, pension benefits reached not only senior citizens, but also other age groups because the pension system does not just offer entitlements for retirement, but also for disability pensions and survivors benefits. Nevertheless, the largest number of beneficiaries were adults over age 60 .

\section{Graph 5}

Beneficiaries of social protection by program and age, Argentina, 2010

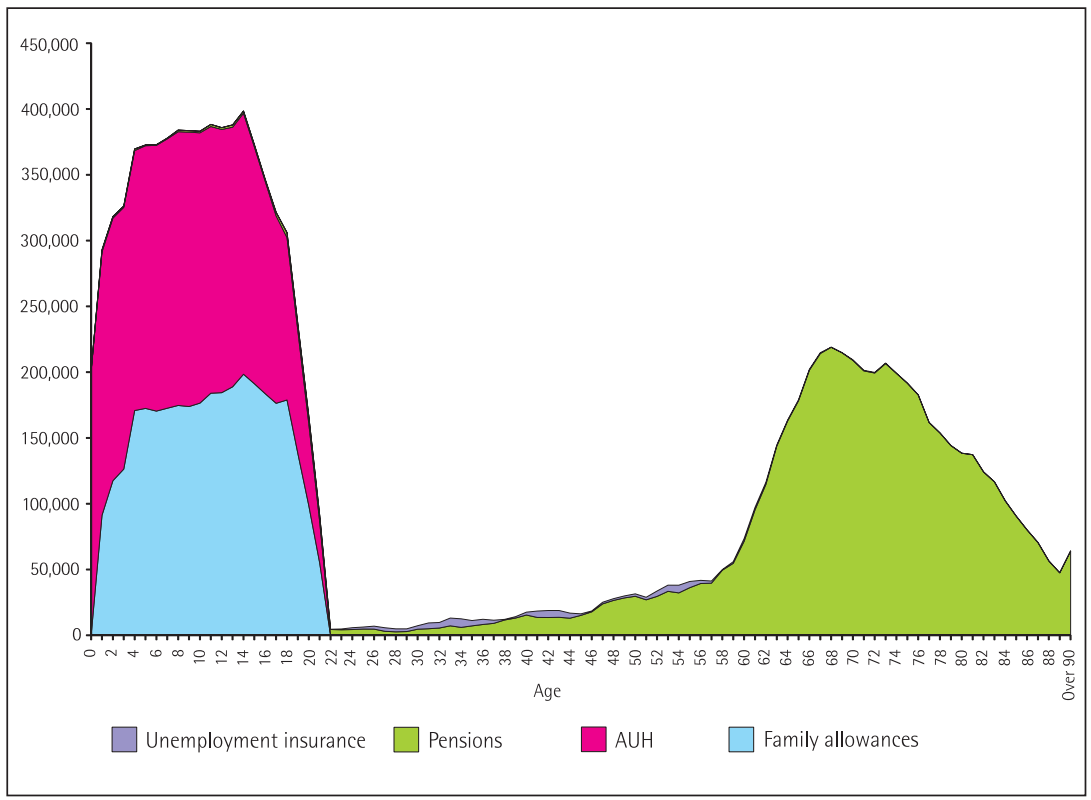

Source: Compiled by authors on the basis of information from INDEC and MTEySS.

In 2010, monetary transfers from social protection, excluding operating expenses, reached 114.691 billion pesos, equal to $8 \%$ of GDP. Based on the distribution of beneficiaries by age group, Graph 6 presents the profile of the total transfers from social protection programs by age group and type of program in 2010 .

The population over 60 receives $72 \%$ of social protection expenditure, primarily through transfers for pensions. In turn, children under age 18 receive 15\% of social protection spending. This asymmetry in the distribution of social protection resources is associated with the differential in the average benefits provided by each program. In December 2010, the average pension benefit was 1,359 pesos, while per child family allowances and the AUH were set at 220 pesos. 


\section{Graph 6}

Total expenditure on social protection by age and program, Argentina, 2010 (as \% of GDA)

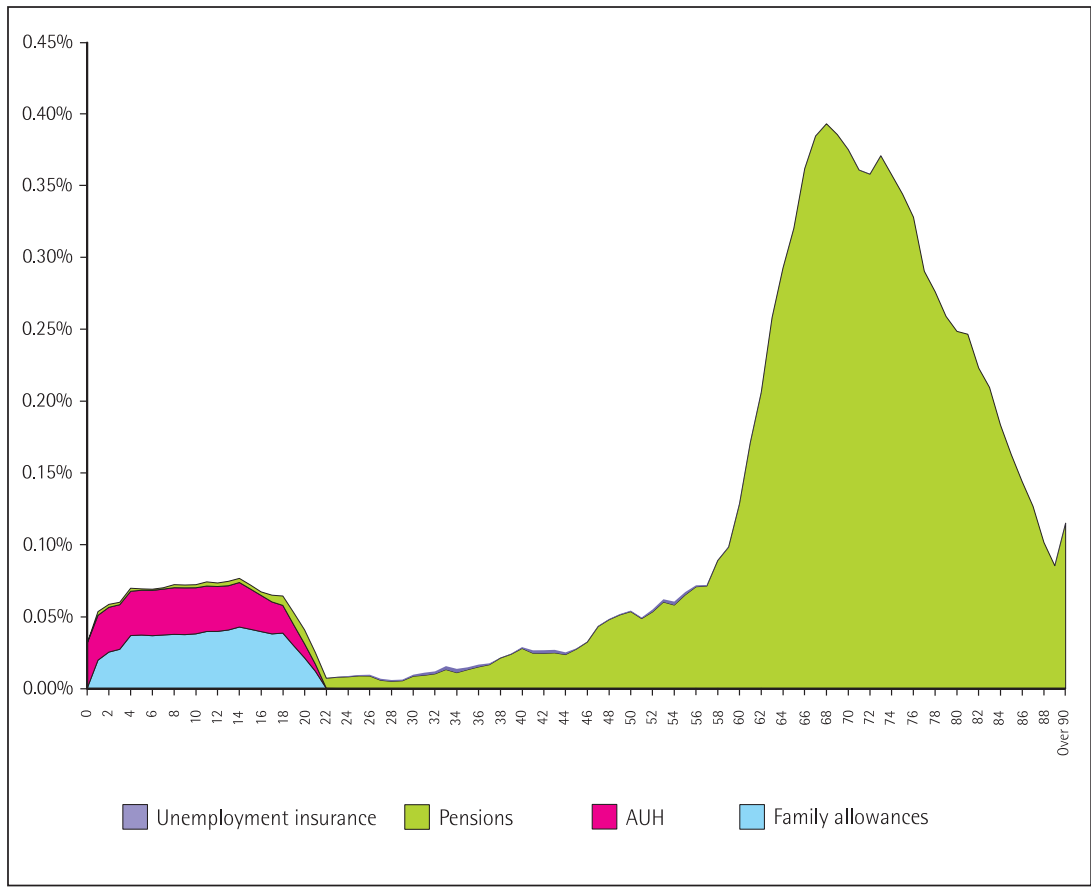

Source: Compiled by authors on the basis of information from INDEC, the Secretariat of Finances, and MTEySS.

Graph 6 demonstrates that total social protection expenditure by age presents a strong bias in favor of senior citizens, and the effect is even more notable if one takes into account per capita expenditures. Graph 7 shows that, based on the information in the preceding graphs, there exists a strong bias in expenditure on senior citizens, who, on average, receive transfers between 10 to 15 times higher than those received by children and youth. This difference is explained by the combination of the high value of pension benefits relative to transfers to children, as well as greater coverage among the elderly.

The differences shown in Graph 7 have sparked debate on the system's intergenerational equity. This discussion has two dimensions. On the one hand, in terms of the period, it is clear that senior citizens greatly benefit from these transfers, although it is possible that part of this difference is compensated for through intra-family transfers (i.e., senior citizens use part of these resources to fund the consumption of their children and grandchildren). 
Even if this were the case, it is worth questioning the reasonableness of a social protection policy with such a strong bias.

\section{Graph 7}

Per capita expenditures on social protection by age and program, Argentina, 2010 (in pesos)

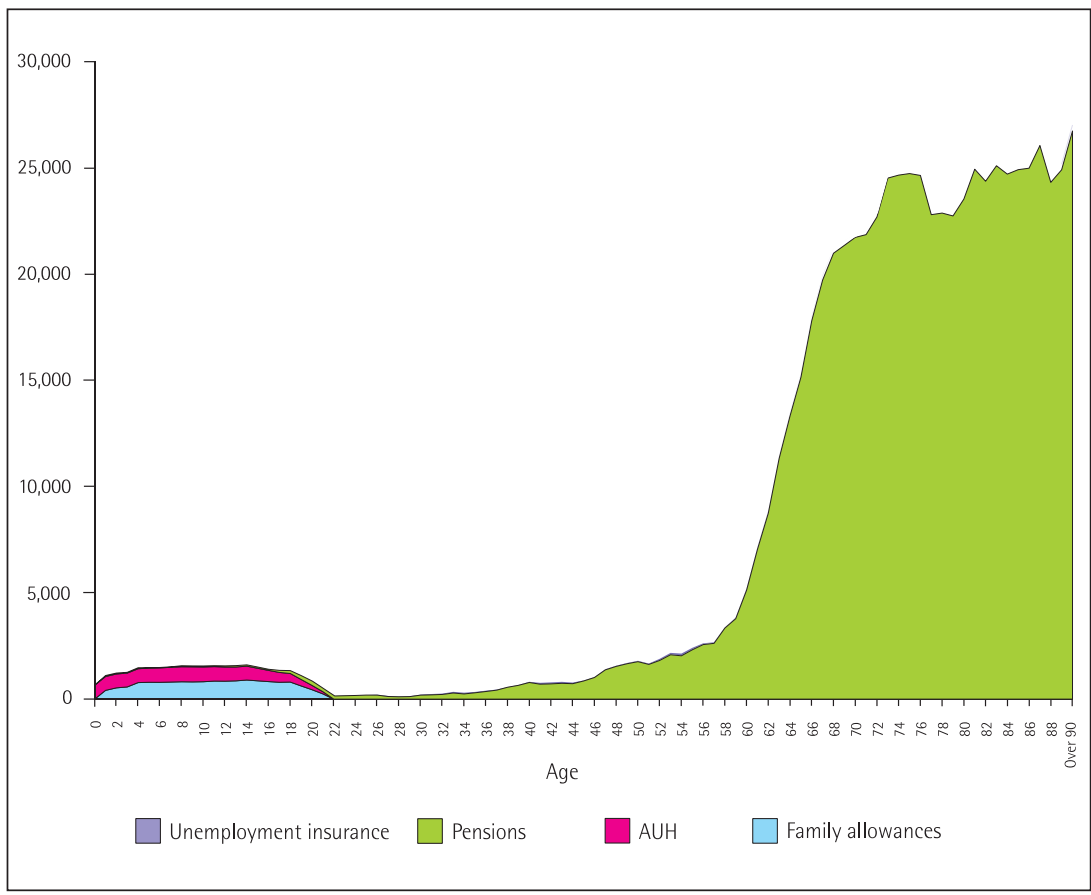

Source: Compiled by authors on the basis of information from INDEC, the Secretariat of Finances, and MTEySS.

On the other hand, in a cohort analysis it would be possible to view this apparent inequity as not so significant. The principal arguments in favor of this point would be that: a) all groups go through childhood and old age during their life cycle, thus eventually all will benefit from this model; and $b$ ) senior citizens who are currently receiving these benefits have made contributions, both through contributory pension systems and through their work and general tax payments throughout their lives, so these transfers basically represent the fruit of their labor during decades past. 
This last argument is associated with the idea that pension benefits constitute deferred salary income. Given the current configuration of the pension system, financed by both salary-based contributions and general tax revenue, both formal and informal workers have made contributions as a way of postponing some of their income from their economically active period to their retirement period.

\section{THE IMPACT OF DEMOGRAPHIC TRENDS AND PUBLIC POLICY ASSUMPTIONS}

In this section, we will perform some simulations of predicted expenditures on monetary transfers for social protection for the period 2010-2100 based on some assumptions about the long-term behavior of certain intervening variables.

The first proposed scenario supposes the continuity of the four programs considered (pensions, unemployment insurance, contributory family benefits, and the AUH) with the same conditions and regulations that currently exist. Under this assumption, it is expected that there will not be any significant changes in the last three programs in terms of eligibility or the value of benefits (which are assumed to stay constant relative to salaries). In contrast, however, the mere application of the current rules will have a significant effect on pension coverage.

As we pointed out in earlier sections, trends in labor formality, combined with the reforms in access requirements for retirement benefits in recent decades signified a declining trend in pension coverage that would have continued if the Moratorium had not been implemented. In an analysis of medium- and long-term trends, Grushka (2011) estimated that if the current rules were maintained, according to which access to benefits requires a history of contributions of at least 30 years, the percentage of senior citizens regularly receiving retirement benefits or a pension would fall without interruption to nearly 50\% in 2040. After that, and assuming a continuous increase in the rate of labor formality of approximately $0.3 \%$ per year, ${ }^{7}$ a recovery would begin, reaching a coverage level of $69 \%$ in $2100 .^{8}$

7. The assumption used here indicates that this increase takes place in the context of a strongly bimodal distribution in terms of the accumulation of contribution years during the economically active period.

8. The assumptions adopted by Grushka (2011) are similar to those utilized by Coppini (2000) and Thullen (1995). 
Based on the aforementioned assumptions, and considering the demographic projection by age, the percentage of senior citizens covered by the pension system would fall to around 2040 and after that, it would recover at a constant rate (Graph 8). The reasons behind this behavior are in part due to the fact that the starting point of the analysis includes the significant impact of a program that is assumed to have closed after 2012 (the Moratorium), and that will gradually fade in importance. Near the midpoint of the predicted period, we can expect that the predicted improvements in labor formality will foster increasing pension coverage for senior citizens.

\section{Graph 8}

Adults over age 65 with income from retirement benefits and/or pensions, Argentina, 2010-2100 (in \%)

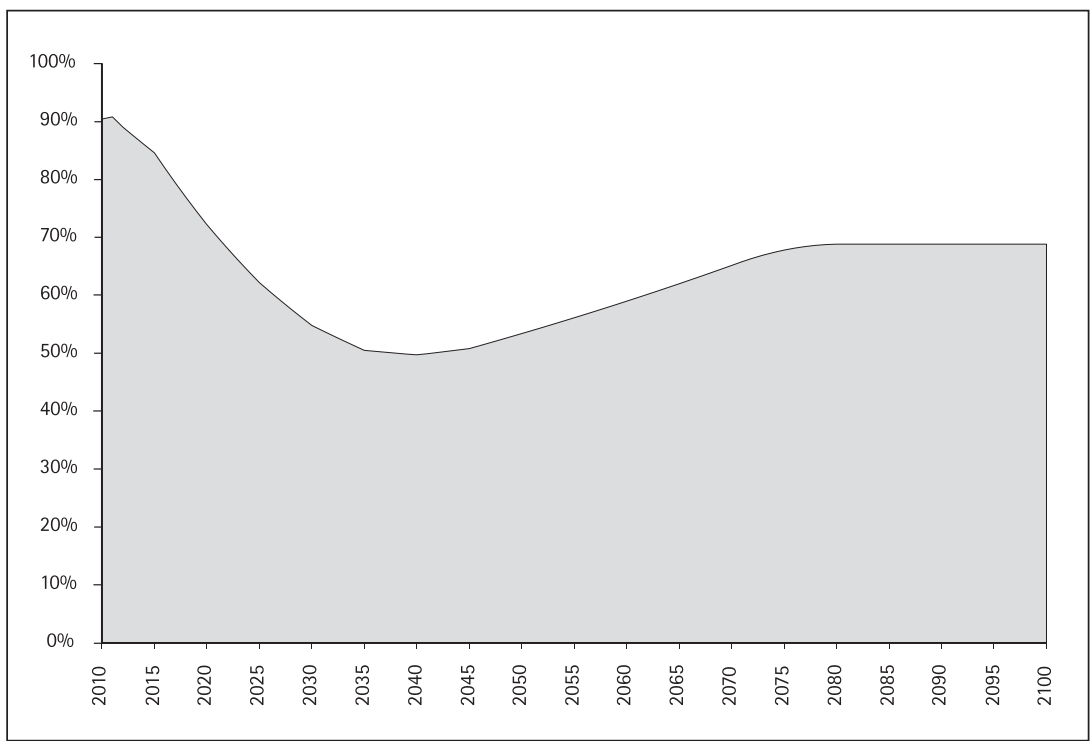

Source: Compiled by authors on the basis of Grushka (2011).

Eligibility requirements and the difficulties in developing the formal labor market allow us to foresee a significant reduction in pension coverage in the coming decades, with a growing proportion of senior citizens lacking access to retirement benefits or a pension. In this context, it appears reasonable to expect an increase during this period of political and social pressures in favor of the implementation of normative reforms that will ease access to benefits. 
Consequently, an alternative scenario that is interesting to evaluate is the possibility of establishing additional benefits that recognize some level of compensation for individuals that contributed to the pension system for a minimum period of time, or that did not join the formal labor market. For example, it is possible to model an alternative scenario that includes allocating a basic benefit, set at $66 \%$ of the current average benefit, which would be distributed in such a way as to maintain coverage of senior citizens at $90.8 \%$. In order to project the cost of this additional benefit, it is necessary to determine the total number of persons entitled to such a benefit. This number of beneficiaries emerges as the difference between contributory coverage and the desired level of coverage.

Based on these coverage projections, the financial effort required to pay these benefits is simulated below. Given that the purpose is to obtain a long-term vision and a structural analysis of the social protection system under relatively stable conditions, we chose to present a scenario in which GDP and salaries grow annually at a real rate of $1.5 \%$, while benefits grow at the same rate as per capita GDP.

The expenditure for each social protection transfer program (pensions, unemployment insurance, and family allowances) at each point of time is defined in the following manner:

$G_{p, t}=\sum_{x=0}^{+90} b_{p, x, t,} \cdot N_{t, x} \cdot \alpha_{p, x, t}$

Where:

$G_{p, t}$ represents the total expenditure for program $p$, during period $t$.

$b_{p, x, t}$ is the average benefit received by beneficiaries at age $x_{1}$ from program $p_{1}$ at time $t$. This value is adjusted over time at the same rate as per capita GDP.

$N_{t, x}$ is the population aged $x$, at time $t$.

$\alpha_{p, x, t}$ is the percentage of the population aged $x$ covered by $p_{1}$ at time $t$.

Graph 9 presents the projected trajectory of expenditures on retirement benefits and pensions as a percentage of GDP under the two proposed coverage scenarios. Given the assumptions adopted, the main difference between the scenarios is the coverage by the system, which in one case would follow the trajectory shown in Graph 8, and in the other, would remain stable at around 90\% for adults over 65 years of age. 


\section{Graph 9}

Projection of total expenditure on retirement benefits and pensions, Argentina, 20102100 (as \% of GDP)

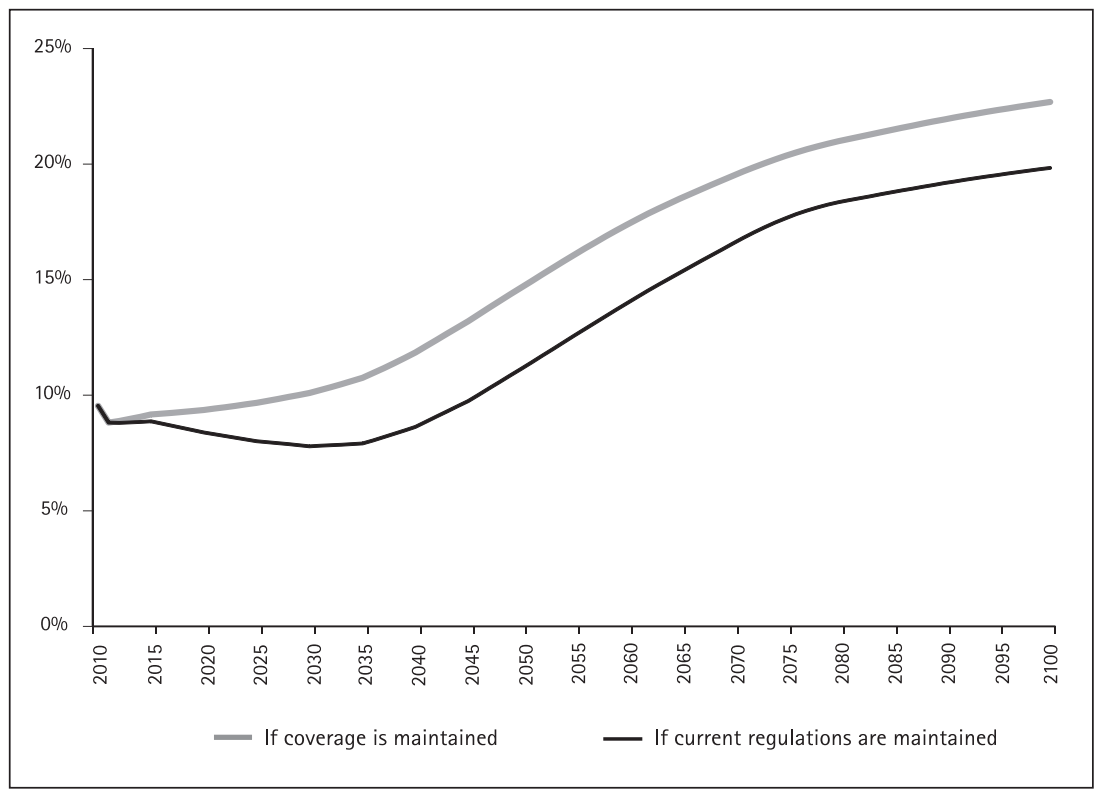

Source: Own elaboration.

Based on these assumptions, if the current regulations are not modified, the aging process will not affect retirement benefits and pensions until the middle of the century because the increasing elderly population will be offset by decreasing coverage. Beginning in 2040, when coverage will start to recover due to projected increases in labor formality, expenditures will also increase and will reach approximately $20 \%$ of GDP by 2100 . In contrast, if a policy were adopted that guaranteed a benefit of at least $66 \%{ }^{10}$ of the average contributory system benefit for $90 \%$ of the population, the increase in spending would be apparent immediately and would reach 23\% of GDP by 2100 .

The projected evolution of expenditures on the other programs follows demographic trends since changes in coverage or level of benefits cannot be assumed. Thus, Graph 10 illustrates that trends in family benefits, both contributory and non-contributory, will decline, given the reduction in the relative size of the population of children and adolescents. This will

10. This value is the current value represented by the Moratorium benefit compared with the average contributory benefit. 
not occur in the case of unemployment insurance because the participation rate among the economically active population will remain stable. Of course, the relative importance of expenditures on these three programs will continue to be minor (and will even decrease) relative to spending on retirement benefits and pensions.

\section{Graph 10}

Projection of expenditures on family allowances, AUH, and unemployment insurance, Argentina, 2010-2100 (as \% of GDP)

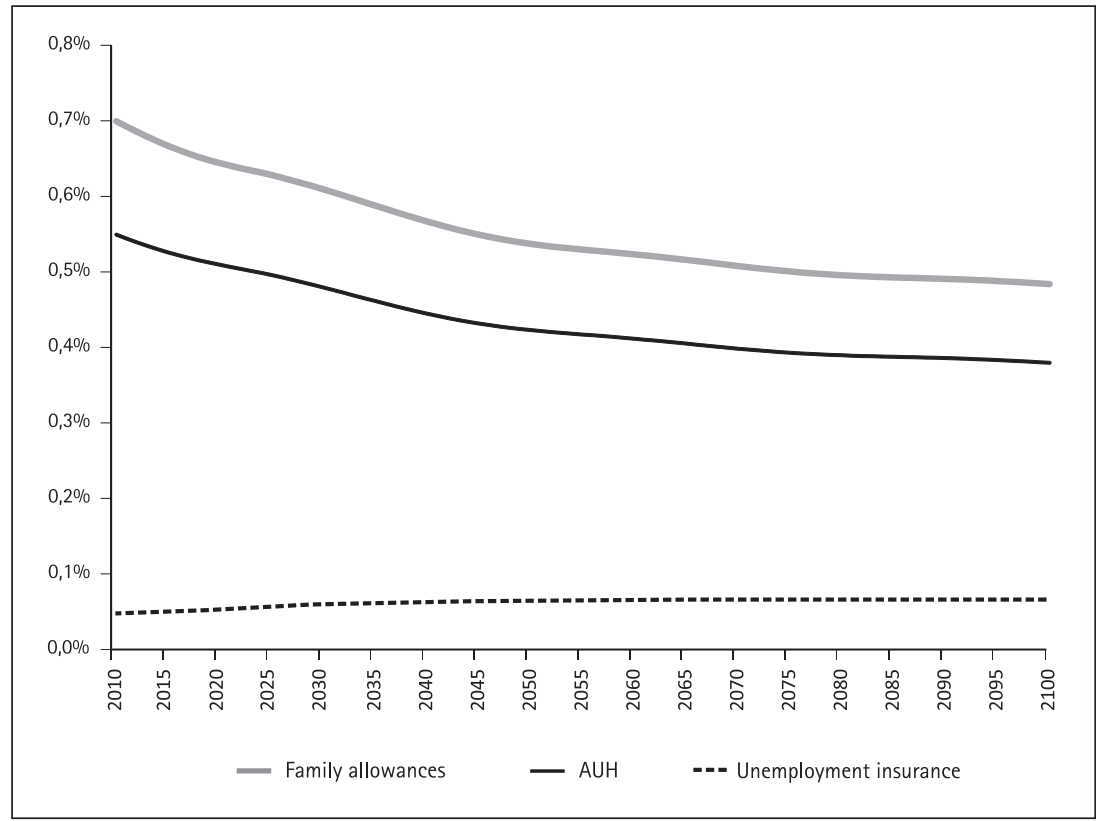

Source: Compiled by authors.

Finally, total expenditure in the sector (i.e., including all four programs considered here), which in 2010 reached 9\% of GDP, will follow an increasing trend under any scenario in the coming decades (Graph 11). If the current regulations of the pension system are maintained, expenditures will reach 21\% of GDP; under an alternative scenario that sustains current coverage levels, they could reach $24 \%$ of GDP. In any case, it is clear that such expenditures will require significant fiscal resources, which the government will have to meet by combining various sources of alternative financing. 


\section{Graph 11}

Projection of total social protection expenditures, Argentina, 2010-2100 (in \% of GDP)

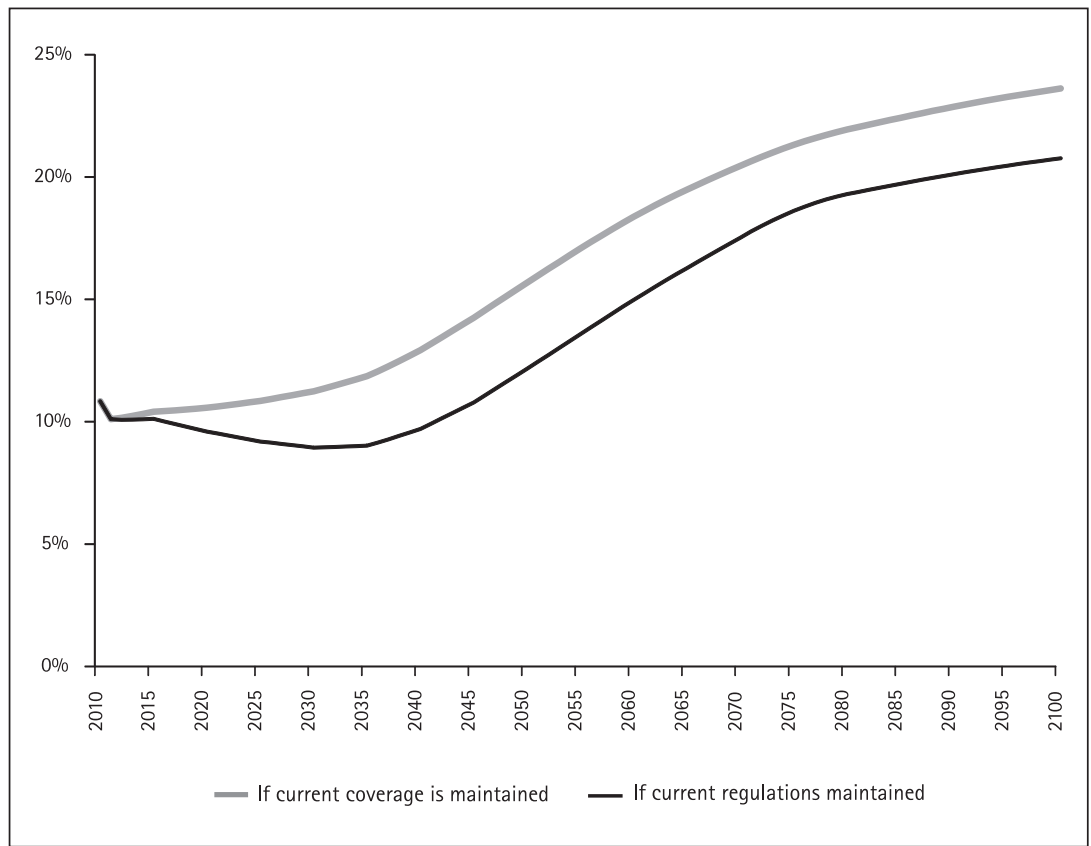

Source: Compiled by authors.

The importance of these projections lie not in the exact identification of the level of expenditures at a particular moment under study but rather in the attempt to gain a better understanding of the possible trends in expenditures on pensions when specific assumptions are made about expected policies. In any possible scenario of implementation of one-time measures, these initiatives have a (downwards) impact on the level of expenditures, even if the tendency is not reversed, to the extent that demographic pressure continues to increase. In contrast, a continuous plan of changes to the rules of the game could also be a continuous mitigating factor of the level of pension distribution, as, for example, would happen if the legal age of retirement were raised according to increases in life expectancy at retirement. In any case, and apart from initiatives intended to contain pension expenditures, one issue that deserves more discussion is the creation of conditions that would assure a path to per capita GDP growth that would permit the financing of a greater demand from the pension system. 


\section{CONCLUSIONS}

Both the actuarial sustainability of the Argentine social protection system (i.e., its ability to maintain a flow of contributory funds sufficient to finance the flow of benefits), as well as the fiscal sustainability (the state's capacity to generate sufficient resources to fund entitlement benefits) will depend on different factors.

On the one hand, as we have seen in this article, the demographic transition process toward an older population creates pressure in that a larger portion of the population is dependent on income from others. Based on our simulated results, it is evident that population aging has a direct impact on the level of monetary transfers made by the social protection system. Currently, Argentina spends about 10\% of GDP on monetary transfers on the following set of social protection programs: family allowances, unemployment insurance, universal per child family allowances, and the pension system.

Under various alternative pension coverage scenarios, the demographic transition process would lead to an increase in future social protection expenditures, reaching 15\% of GDP during the 2050s and surpassing 24\% in 2100.

Under any scenario, beginning in the mid-2030s, a period of growing demand for government spending could begin. This would be the result of the end of the demographic dividend and the consequent increase in the number of retired senior citizens relative to the young economically active population. In other words, the baby boomers of the 1970s and 1980s will be senior citizens by the 2040s-2060s, thus increasing the financial requirements for sustaining their consumption.

However, some changes in personal behavior could lessen, and even offset, the effect of aging on the dependency of senior citizens. The dependency ratio is a static indicator, insomuch as it is defined by the age of the population. Nonetheless, it is not in and of itself a determinant of a personal decision to retire from the labor market. In effect, the tendency observed in Argentina, as well as in other countries of the region, is that senior citizens postpone their retirement from the labor market. According to information from CELADE, a continuous increase in the economic participation of the elderly is predicted, especially among workers age 65 to 79. This behavior represents a natural extension of the retirement age and thus removes financial pressure from the social protection system.

In any case, medium- and long-term social protection policies, and especially those involving pensions, cannot wait for a possible evolution of the dependency ratio. An adequate forecast 
of outlays and sources of funding is necessary. Currently, the Argentine pension system is funded in part with purely contributory resources (payroll contributions), although it also requires alternative sources of financing, especially those from tax revenues. The utilization of funds other than those collected from the social protection system to fund pension commitments has occurred for decades, and even though labor formality increased in the last ten years, there is still a high percentage of people in the informal sector. 


\section{APPENDIX}

Table 1

Projection of total expenditures for social protection, Argentina, 2010-2100 (in \% of GDP)

\begin{tabular}{|c|c|c|c|c|c|}
\hline \multirow{2}{*}{ Year } & \multirow{2}{*}{$\begin{array}{c}\text { Family } \\
\text { Allowances }\end{array}$} & \multirow{2}{*}{ AUH } & \multirow{2}{*}{$\begin{array}{l}\text { Unemployment } \\
\text { Insurance }\end{array}$} & \multicolumn{2}{|c|}{ Pensions } \\
\hline & & & & $\begin{array}{c}\text { Coverage at } \\
90 \%\end{array}$ & $\begin{array}{c}\text { Current } \\
\text { Regulations }\end{array}$ \\
\hline 2010 & 0.7 & 0.5 & 0.0 & 9.5 & 9.5 \\
\hline 2020 & 0.6 & 0.5 & 0.1 & 9.4 & 8.4 \\
\hline 2040 & 0.6 & 0.4 & 0.1 & 11.8 & 8.6 \\
\hline 2060 & 0.5 & 0.4 & 0.1 & 17.4 & 14.0 \\
\hline 2080 & 0.5 & 0.4 & 0.1 & 21.0 & 18.4 \\
\hline 2100 & 0.5 & 0.4 & 0.1 & 22.7 & 19.8 \\
\hline
\end{tabular}




\section{BIBLIOGRAPHY}

BERTRANOU, Fabio and Damián BONARI

2005 Protección social en Argentina. Financiamiento, cobertura y desempeño 1990-2003. Buenos Aires: Oficina Internacional del Trabajo.

CEPAL, COMISIÓN ECONÓMICA PARA AMÉRICA LATINA Y EL CARIBE

2012 Proyecciones de población. Santiago de Chile: CEPAL. <http://repositorio.cepal.org/bitstream/ handle/11362/7118/S2012922_mu.pdf?sequence $=1>$.

COPPINI, M.A.

1999 Técnicas de los seguros sociales, vol. I and II. Geneva: AISS.

GASPARINI, Leonardo and Guillermo CRUCES

2010 "Las Asignaciones Universales por Hijo en Argentina. Impacto, discusión y alternativas." In: Económica, no. LVI, pp. 105-146.

GRAGNOLATI, Michele; Ole H. JORGENSEN; Romera ROCHA and Anna FRUTTERO (eds.)

2011 Growing Old in an Older Brazil. Implications of Population Aging on Growth, Poverty, Public Finance, and Service Delivery. Washington, D.C.: World Bank.

GRAGNOLATI, Michele; Rafael ROFMAN; Ignacio APELLA and Sara TROIANO (eds.)

2013 Los años no vienen solos. Oportunidades y desafíos económicos de la transición demográfica en Argentina. Buenos Aires: Banco Mundial.

GRUSHKA, C.

2011 "Evolución y perspectivas del SIPA" [mimeo.]. Buenos Aires: Universidad Nacional de General Sarmiento.

ISUANI, Ernesto and Jorge SAN MARTINO

1995 "El nuevo sistema previsional argentino. ¿Punto final a una larga crisis?" In: Boletín Informativo Techint, no. 281.

MTEySS

2005 "Prospectiva de la previsión social. Valuación financiera actuarial del SIJP 2005/2050." Buenos Aires: Secretaria de Seguridad Social.

ROFMAN, Rafael; Leonardo LUCHETTI and Guzman OURENS

2008 "Pension Systems in Latin America: Concepts and Measurements of Coverage." Discussion Document no. SP 616. Washington, D.C.: World Bank.

ROFMAN, Rafael and Maria Laura OLIVERI

2012 "Un repaso sobre las políticas de protección social y la distribución del ingreso en Argentina." In: Económica, no. LVIII, pp. 92-123. 
2011 "Las políticas de protección social y su impacto en la distribución del ingreso en Argentina." Documento de Trabajo sobre Políticas Sociales No. 6. Buenos Aires: Banco Mundial.

THULLEN, Peter

1995 Técnicas actuariales de la seguridad social: regímenes de las pensiones de invalidez, de vejez y sobrevivientes. Madrid: Ministerio de Trabajo y Seguridad Social.

\section{Databases}

AIF-ANSES

INDEC

MTEySS

Secretaria de Hacienda 